\title{
The arguments for a permanent zero interest rate
}

\author{
Ralph S. Musgrave
}

\begin{abstract}
A zero interest rate regime is one where government issues a form of money which pays no interest, but does not borrow. There are three reasons for that policy. First, most if not all the reasons given for government borrowing are hopeless. Second, adjusting interest rates is a policy which is riddled for anomalies. E.g. in order to be able to cut interest rates, government first has to artificially raise them. But artificial adjustments to the price of anything, including the price of borrowed money does not make economic sense. Third, the market failure which causes recessions is not the failure of interest rates to fall. It's the failure of wages and prices to fall, which would increase the real value of base money and government debt (if there is any), which in turn would encourage spending. That's the "Pigou effect". If government and central bank were simply to create new base money and spend it (and/or cut taxes) in a recession, that would come to much the same as the Pigou effect. That is what might be called a "free market compliant" policy. Interest rate adjustments are not "compliant". Thus government should not borrow other than for very good reasons, if there are any, and artificial adjustments to interest rates should cease, except perhaps in emergencies. That, for want of a better phrase, can be described as a "permanent zero interest rate" policy. That policy is not far from the UK Labour Party's new fiscal rule.
\end{abstract}

Keywords: permanent zero interest rate, government borrowing, Pigou effect.

\section{INTRODUCTION}

There are two fairly closely related ideas that have been around for some time. One is that government should not borrow, and the second is that governments and central banks should do nothing to influence interest rates, i.e. the determination of interest rates should be left to market forces. The latter idea amounts to and is sometimes called a "permanent zero interest rate" policy. Friedman (1948, Section II), Mosler (2010, 2nd last paragraph), Mitchell (2015) and Forstater and Mosler (2005) advocated those sort of ideas. The purpose of this paper is to improve on the latter works.

In contrast to a zero interest rate regime, governments and central banks in the real world influence interest rates for three reasons.

First, governments for a long time have borrowed significant sums purely to enable politicians to ingratiate themselves with voters: voters tend to blame politicians directly for tax increases, whereas voters tend not to see the interest rate rises that stem from excess government borrowing as being the fault of politicians. Thus politicians are always tempted to borrow too much. Hume (1742) noticed that phenomenon: some of Hume's observations are set out in section 2.11 below. And Simon Wren-Lewis refers to that phenomenon as the "deficit bias", e.g. see Wren-Lewis (2018).

Second, and as distinct from the latter clearly unjustified reason for government borrowing, there are several popular arguments for such borrowing which seem reasonable but which are in fact flawed. Section 2 below sets out those flaws. 
Third, central banks adjust interest rates so as to adjust demand. It is argued in section 3 below that there is a basic theoretical flaw in that idea: the "Pigou effect" flaw mentioned in the abstract above.

The conclusion is that demand is best adjusted by adjusting the amount of base money that government and central bank create, with interest rates being left to find their own level, although it is conceded that interest rate adjustments might be justified if used only occasionally and in emergencies.

The word "state" refers here to government and central bank combined, while the word "government" refers to government alone and "CB" to the central bank alone. Commercial banks are referred to simply as "banks". Instead of the word "infrastructure", the phrase "public investment" is used since there are forms of public investment other than infrastructure.

As to why little or no government borrowing equals or more or less equals a permanent zero interest rate regime, there is first the above mentioned fact that governments are large borrowers, thus if they cease borrowing, interest rates will obviously decline.

Second, if the state borrows little or nothing, and assuming the amount of state liability that the private sector wants to hold remains constant, it follows that the only other form of state liability, i.e. base money must expand. Indeed, that is exactly what has happened over the last five years or so in the guise of quantitative easing: that is, states have created large amounts of fresh base money and bought up government bonds. The result has not been a dramatic increase in demand or hyperinflation caused by recipients of that new money trying to spend away their newly acquired money. That is, it seems that the amount of state liability that the private sector wants to hold has remained approximately constant. Plus the result of that exercise is that banks are now awash with reserves, thus the device that central banks used to employ to raise interest rates, i.e. keeping banks short of reserves, no longer operates.

Of course central banks can pay interest on reserves so as to raise interest rates. But that amounts to much the same as rewarding people (at the taxpayers' expense) for storing wads of hundred dollar bills under their mattresses. The logic there, to put it politely, is far from clear. There would be some logic there if there were good theoretical reasons for using artificial interest rate adjustments to adjust demand, but the theory behind artificial interest rate adjustments is shown to be flawed in section 3 below.

The discussion below assumes that government is "monetarily sovereign", that is, government together with its CB issues its own money: that applies to countries like the US or UK which have their own form of money (the US dollar and the Pound). Although the same arguments apply to common currency areas like the Eurozone, care needs to be taken in applying the arguments to individual Eurozone countries, i.e. countries which do not issue their own currencies. The exact way in which these arguments apply to individual Eurozone countries is not considered here.

A permanent zero interest rate policy is not a hundred miles from the UK Labour Party's new fiscal rule. That rule says that stimulus should be implemented via interest rate cuts except where the rate of interest has declined to near zero, at which point fiscal stimulus (i.e. having government borrow money and spend it and/or cut taxes) can kick in. That rule would result in central bank base rates always tending towards zero. 
Earlier versions of this paper were placed at thesis repositories: Musgrave (2018a and 2018b).

\section{POPULAR BUT FLAWED ARGUMENTS FOR GOVERNMENT BORROWING}

\section{Government bonds provide a means of saving?}

One argument for government borrowing is that relevant bonds provide savers with a means of saving, and that seems to be a popular argument to judge by Mitchell $\left(2015,1^{\text {st }}\right.$ paragraph) and Murphy (2018).

However, without government bonds, and assuming the state simply supplies the economy with whatever amount of base money is needed to induce everyone to spend at a rate that brings full employment, which is the policy advocated here, savers would be free to stock up on as much zero interest yielding base money as they like. That is, under the regime advocated here, any increased desire by the private sector to save or hoard base money is easily accommodated by the state issuing more of the stuff.

As to whether savers have any sort of moral right to interest on their savings, it is hard to see why, particularly given that it is taxpayers who fund that interest: it is not clear why money should be confiscated from one set of people (taxpayers) simply because another set want more interest on their savings than is available from private sector investments.

Another argument for government bonds is that they may encourage saving. Unfortunately while the artificially high rate of interest brought about that policy would certainly encourage savers to hold a larger stock of base money (the extra stock being in the form of interest yielding base money, possibly bonds) it would result in a smaller stock of real savings: real in the sense of physical assets, investments in education and so on. In short, the population would have a larger stock of an entirely artificial or fictitious asset (i.e. base money, any amount of which can be created at the press of a computer keyboard button), and a smaller stock of what really matters, that is, real assets. In particular, mortgagors would have to pay more interest and thus live in smaller houses. That all makes the "encourages saving" idea look very defective.

Another argument for government bonds (cited for example by Murphy (2018)) is that those bonds provide banks with a form of collateral when they need a quick loan from the CB. Well it seems a bit strange to argue that taxpayers should have to pay extra tax just to help banks (aka "money lenders") out of trouble when they are short of cash. If a bank is short of cash, and cannot provide adequate collateral for a loan other than in the form of government debt, then effectively the bank is bust and should be closed down (while depositors are protected of course).

Certainly banks themselves treat those who borrow from them (e.g. small businesses) in that sort of harsh commercial manner. There is no reason for banks themselves to get more favourable treatment than they themselves apply to others. And if the latter harsh commercial policy causes the failure of a large bank, the systemic risk can be dealt with by having the state take over the bank temporarily or permanently, exactly what the British government did with Royal Bank of Scotland recently.

\section{Smoothing out receipts from tax}

Another argument for government borrowing is that it allegedly smooths out irregularities in government income derived from tax: more money arrives in government coffers from tax in some months than others. 
The latter idea is in fact a classic example of one of the most common mistakes in economics, namely extrapolating from the microeconomic to the macroeconomic. That is, if a microeconomic entity like a household or firm is short of cash for a few months, it has to do something about it: e.g. ask the bank for a temporary loan.

In contrast, no such problems face a state: for the months when receipts from tax are less than usual, states can simply print money, and do some "unprinting" during months when receipts from tax are higher than normal. Of course that arrangement involves government borrowing in that government borrows from the $\mathrm{CB}$, but there is no borrowing involved in the sense of the state borrowing from the private sector.

As for the idea that during the months when receipts are lower than normal (i.e. when the private sector has more than a normal amount of cash) the private sector will go on a spending spree with that cash, that is unlikely: to illustrate, if a private sector entity knows it needs to pay $\$ Y$ in tax a few months' time, and has about \$Y more than it really needs in the bank, it is unlikely to go on a spending spree with that cash.

\section{Funding public investments}

Another popular argument for government borrowing is that it can fund public investments. Indeed, so popular is that idea that it has its very own name: the "golden rule". Or to be more exact, the golden rule is the idea that government should borrow only to invest, not to fund current spending.

One important anomaly in the golden rule is that education is a big investment, but it is never suggested that borrowing should fund all education. It is widely accepted that "investment" means expenditure which yields benefits over several years or decades and education certainly has that characteristic. In short, advocates of the golden rule seem to think it applies to physical investments, but not necessarily to intellectual investments.

Of course the types of education that are funded via borrowing (including borrowing by those receiving the education) rather than tax varies from country to country. But certainly the first ten years or so of education in most countries (kid's education) is normally funded via tax, for those who choose state education rather than private education for their kids.

\section{Investment justifies borrowing?}

Another factor which makes the golden rule appealing is that borrowing often funds investments in the private sector, from which it seems to be deduced that investment automatically justifies borrowing. Unfortunately that argument is flawed.

Few entities (households, corporations, etc) borrow to make investments if they have enough spare cash to fund the investment. There is clearly no point in paying interest to anyone when you do not need to. And governments have a near inexhaustible source of cash, namely the taxpayer. In addition, the state can print a limited amount of money in most years.

Moreover, it is not even true that it is just investments that justify borrowing: it can perfectly well make sense to fund consumption / current spending via borrowing. For example if a credit-worthy individual wants to spend money on a consumption item (e.g. a wedding and honeymoon) and repay the money over a few years, there would no good reason for a bank to turn down that loan application. 
To summarize, the justification for borrowing is not the fact of making an investment: it is the fact of being short of cash.

And finally, for some more arguments against the golden rule, see Kellerman (2006).

\section{Spreading costs over generations}

Another popular argument for funding public investment via borrowing is that such borrowing allegedly spreads the cost of the investment over the generations that benefit from the investment: i.e. future generations allegedly pay part of the cost in that they have to pay interest on the loans and repay the principal.

However, that argument is flawed: it assumes time travel is possible! To illustrate, the real resources required to build a bridge in 2018 (steel, concrete, person-hours, etc) cannot possibly be supplied by people living in 2030: the laws of physics (never mind the laws of economics) dictate that the steel etc must be supplied by those living in 2018 or earlier.

As for the idea that future generations must repay the debt incurred to create public investments, future generations do not just inherit that liability: they also inherit an asset, namely the bonds that fund public investments. The latter liabilities and assets cancel each other out.

The only exception to the latter "zero inheritance" point arises where one country or city borrows from other countries or cities so as to fund investments, as explained by Musgrave (1939). That is, it is clearly physically possible for country A to supply the physical goods and/or labour needed to create an investment in country B in any given year, with physical goods etc flowing the other way in subsequent years so as to repay the debt. (Incidentally Musgrave did not actually advocate the latter cross border method of funding public investments: he simply pointed to the fact that cross border arrangements could in theory be used to spread costs across generations.)

But any country trying to exploit the latter "Musgrave" phenomenon with a view to spreading costs across generations faces an obvious problem: if country A tries to induce country B to fund its public investments, there is nothing to stop country B doing the reverse, that is trying to get country A to fund country B's public investments! Indeed most countries have significant holdings of the debt of other countries, which makes the entire "get future generations to pay" idea very questionable.

\section{Is time travel is possible?}

In contrast to the above claim that time travel is not possible, Rowe (2012) claimed time travel is in a sense possible. Rowe's argument was as follows.

Say a government funds investment in a particular decade via borrowing. The relevant bonds will be bought by people of working age saving for retirement. Then, during their retirement, they will sell those bonds, or at least some of them to the next generation, which in turn is saving for retirement.

That process can clearly continue for several generations, until the final generation. Instead of benefitting from the bonds during that generation's retirement years, the money it saves is simply used to write off relevant government debt, and that is clearly an imposition on, or a cost born by the last generation. 
Of course the cost of relevant investments does not have to be loaded entirely onto the last generation: it can be spread across each generation between the initial investment and the disappearance of the last bonds. But it is still an idea on a hiding to nothing because governments make roughly the same amount of public investment every year, thus the whole attempt to "spread the cost across several generations" is a bureaucratic waste of time.

Moreover those of working age already engage in a fair amount of "bond purchasing from oldies": that is how funded pension schemes work. That is, those pension schemes work by having those of working age purchase assets, including bonds, which in their retirement are then sold (so as to fund relevant retirement years), and some of those assets will be sold to people of working age at that time. So the fact that "purchasing bonds from oldies" takes place anyway is a second reason for thinking that any attempt to accurately apportion the cost of public sector investment over several generations is a waste of time.

\section{Borrowing for public investments smooths out taxation?}

Another argument for having borrowing fund public investments is that borrowing can smooth out tax payments: public investments sometimes involve very large sums which are spent in a relatively short period of time, and that spending would arguably lead to large rises and falls in tax if those investments were funded via tax.

The flaw in that argument is that for any large or medium size country, the total amount spent on public investments does not vary much from year to year, thus there is little smoothing to be done. Moreover, it is not even desirable to have such spending vary much from year to year because such variations lead to increased costs: in years when there is little spent on roads for example, those with skills in road construction migrate to other industries, thus they are hard to find come the next boom in road construction. Plus relevant capital equipment tends to be left lying idle during years when there is little road construction.

\section{Borrow more when interest rates rise?}

A final anomaly in the idea that borrowing should fund public investment and that those bonds should be used by the state to adjust interest rates is this. Normal procedure by households and businesses is to borrow less when interest rates rise, and presumably that logic should also apply to government borrowing to fund public investment.

But when CBs want to raise interest rates, they do so by among other things selling government bonds. I.e. the state as a whole borrows MORE rather than less!

\section{Public investment summarized.}

At least four weaknesses in the idea that borrowing should fund public investments have been set out: 1, the education anomaly in the golden rule, 2, the idea that investment justifies borrowing was shown to be invalid, 3 , the future generations idea was shown to be invalid, and 4 , the tax smoothing idea was shown to be invalid. Thus the idea that government borrowing is justified if it funds public investments is clearly very questionable.

However, let's be generous towards advocates of government borrowing, and assume that at some point they manage to explain why such borrowing is justified and what the optimum amount of such borrowing is, perhaps as a percentage of GDP or of public spending.

That would still not justify interest rate adjustments, and for the following reason. 
If government borrows for a good reason, it seems odd to claim that if demand needs raising by a few percent, the state should then print money and buy back relevant bonds so as to cut interest rates, because that amounts to funding public investment via printed money. Put another way, if there are solid reasons for funding public investments via borrowing, the advocates of interest rate cuts need to explain why those allegedly solid reasons suddenly evaporate when demand needs raising.

\section{Borrowing with a view to stimulus}

Another argument for government borrowing is the fact that having government borrow money and spend it, and/or cut taxes is stimulatory. While "borrow and spend" is doubtless stimulatory, it is not obvious what the merits of the "borrow" part of that process are: the fact of borrowing in isolation is clearly deflationary or "anti-stimulatory". That is, the simple fact of borrowing money and doing nothing with the money concerned is deflationary.

The alternative is to have the state simply print base money and spend it. "Print and spend" does not have any "anti-stimulatory" element.

A possible argument for "borrow and spend" is that it is easier to reverse than "print and spend": it is easy for the CB to sell some of the bonds in its possession so as to raise interest rates. However that argument is debatable and for the following two reasons.

i) The fact of having implemented some "print and spend" does not stop CBs raising interest rates: that is, absent government bonds, there is nothing in principle to stop a $\mathrm{CB}$ offering to borrow at above the going rate with a view to raising interest rates and where the latter strategy is not allowed under existing legislation, there is no good reason for not changing that legislation.

ii) The latter novel way of raising interest rates might seem to clash with one of the basic claims of this paper, namely that interest rate adjustments should be abolished or at least should be used more sparingly. In fact the latter "borrowing by the CB" method of raising interest rates is simply a concession to political realities: i.e. it is not a good technical argument or a good argument so far as economics goes.

To expand on that, there are no strictly technical or economic arguments against reversing a bout of "print and spend" with tax increases or public spending cuts (the choice between which would depend on the ideological preference of the party in power). However, unfortunately there can be political problems stemming from tax increases or public spending cuts.

Thus (to repeat), the above mentioned apparent clash is not a clash so far as strictly technical or economic matters go: it is simply a concession that may need to be made to political realities. That is, the latter concession does not weaken the basic argument in this paper, namely that the arguments for government borrowing are feeble.

In particular, the above mentioned tax increases or public spending cuts, if implemented properly, would not need to have any effect on real living standards.

The reason for that is that assuming the 2\% inflation target is the best compromise between raising numbers employed as far as possible and avoiding excess inflation, then any move towards that $2 \%$ is on balance beneficial. Thus where inflation is above $2 \%$, then reducing it to $2 \%$ will be beneficial. Put another way, where excess demand is reined in by tax increases or public spending cuts, the effect ought to be to increase rather than reduce GDP, counterintuitive as that might be. 
As to the possibility that $2 \%$ is the wrong number and that say $4 \%$ might be better, that may be a valid point, but it makes no difference to the latter argument: all that needs to be done is to replace "2\%" with " $4 \%$ " in the latter couple of paragraphs.

The conclusion is that where it is politically expedient to cut demand by artificially raising interest rates, that artificial rate rise should be reversed as soon as possible, with tax increases and/or public spending cuts taking the place of the latter rate rise, the result being that the permanent zero interest rate regime is re-established.

\section{Irresponsible borrowing by politicians}

A further argument for government borrowing is that politicians should have the right to borrow if they see fit. In fact politicians are often grossly irresponsible in that connection. Indeed, one of the worst cases of that irresponsibility is taking place at the time of writing in the US.

That is, over the last few years Republicans have complained incessantly about the alleged excessive deficit and debt. But those complaints were largely or wholly unjustified given that a larger than normal deficit was needed to escape the recession. As for the motive for those complaints, the motive was simply to cast doubt on the economic competence of Democrats. (Plus the Conservative Party in the UK has been up to similar trickery.)

Worse still, now that Republicans are in power and given that the recession is, at the time of writing, all but over, there is clearly no need for a large deficit, or even a need for any deficit at all. But Republicans have let the deficit go through the roof!

Moreover, this is not the first time Republicans have complained about the deficit when not in power, only to implement record size deficits when in power. It is difficult to imagine how Republicans could be more irresponsible and dishonest if they tried.

The conclusion is that giving politicians the power to borrow is equivalent to putting a fox in charge of a hen house. As Hume (1742) put it, the freedom to borrow, if granted to politicians "....will almost infallibly be abused".

In fact, given the scarcity of good arguments for government borrowing, it is legitimate to ask exactly why such borrowing takes place, and Hume arguably got the answer right there as well. As he said in the sentence before the latter quote, "It is very tempting to a minister to employ such an expedient, as enables him to make a great figure during his administration, without overburdening the people with taxes, or exciting any immediate clamours against himself."

\section{Why boost just borrowing in a recession?}

Another argument for interest rate adjustments is that come a recession, it is desirable to increase lending and borrowing rather than increase one of the other elements of aggregate demand, like consumer spending or exports. In fact there is no obviously good reason for that. Certainly when CBs cut interest rates, they do not do so on the basis of detailed research showing the decline in demand is due to an entirely irrational fall in lending, rather than a fall in say consumer spending. (Note that if a fall in lending is attributable to rational rather than irrational factors, then there is no reason to boost lending rather than boost consumer spending and/or public spending.)

Moreover the basic purpose of the economy is to produce what the consumer wants (both the items the consumer chooses to buy out of disposable income and the items which consumers 
vote at election time to have supplied to them via public spending). Thus given a fall in demand, the obvious and simplest solution is to boost consumer and public spending.

As to investment, firms supplying "disposable income" items and public sector entities supplying "voted for" items are well able to decide for themselves whether the extra demand warrants extra investment.

\section{Interest rate adjustments work quickly?}

A possible argument for government debt and the interest rate adjustments so facilitated is that interest rate adjustments work more quickly and/or predictably than fiscal adjustments.

Clearly interest rates can be adjusted by CBs at the flick of a switch. But whether those adjustments actually result in mortgage rates and other rates out in the real world changing all that quickly is debatable. Even when mortgage rates do change, there is a further substantial delay before the really important change comes: extra construction jobs. Dyson (2010 et al: p.10) cites evidence on the ineffectiveness of interest rate adjustments.

Although in some countries the pace at which fiscal adjustments take place is slow, for example in the US, in the UK the finance minister has the power the change some taxes instantaneously. A CB could also have the right to implement such adjustments itself (e.g. an increase or cut in payroll taxes), given too much delay by politicians, although in a democracy, politicians should obviously have the right at a later date to cancel those CB implemented fiscal adjustments and replace them with different ones.

\section{Government borrowing helps the rich lend to the poor?}

Given that the more a government borrows, the less the tax that taxpayers need pay, and given that everyone, including the poor are taxpayers, it follows that in effect, government borrowing helps the rich lend to the poor. And that might seem to be an argument for government borrowing.

The problem there is that the state, as an intermediary between rich and poor, is a subsidised intermediary: states have powers not possessed by normal banks, or other intermediaries. States can imprison taxpayers and borrowers who do not pay their dues. Banks cannot.

Plus states can create limitless amounts of a form of money which is a net asset from the private sector's point of view. Banks cannot do that: it is true that banks create money, but that money is not a net asset for the private sector. That "right to print" possessed by states amounts to a subsidy or potential subsidy of states as intermediaries between rich and poor.

The normal view in economics is that subsidies do not make sense unless there is a good social case for them.

\section{Artificial interest rate cuts}

As distinct from artificial interest rate increases, it is possible for CBs to artificially cut interest rates by creating base money and buying commercial bonds. However that involves CBs in taking commercial risks which is not what CBs were set up for. In addition, there are the various reasons given elsewhere in this paper for thinking that any artificial interest rate adjustment is undesirable. The conclusion is that all forms of tampering with interest rates are undesirable, apart from the temporary interest rate adjustments mentioned in section 2.10 above. In that sense, a permanent zero interest rate is the best option. 


\section{The Pigou effect}

\section{THE PIGOU EFFECT}

One good reason for state intervention in the market is to put right defects in the market - i.e. deal with so called "market failure". So if it can be shown that interest rates do not fall as far or fast in a recession as they would in a perfect market, that would be a reason for artificially boosting interest rate falls in a recession.

Unfortunately it is not obvious what is to stop market forces working in that connection: there are millions of borrowers and lenders, and hundreds of banks and similar intermediating between borrowers and lenders. That is the sort of scenario where market forces normally work reasonably well. Thus it is not clear why it is necessary to artificially boost any fall in interest rates that might happen in a recession.

As regards the latter suggestion that there is little to stop interest rates changing in sympathy with market forces, and hence that interest rate changes by CBs are entirely artificial and do not address a market failure, it might seem that much the same applies to fiscal stimulus.

In fact there is a big obstruction in the way of the free market's equivalent to fiscal stimulus (or at least what is classified as fiscal stimulus here, namely having the state create new money and spend it, and/or cut taxes).

In a perfectly functioning free market which is hit by some sort of demand reducing shock, wages and prices would fall in the resulting recession, which would increase the real value of money (and the real value of government debt). As Arthur Pigou explained, that increase in the real value of the private sector's stock of liquid assets would induce the private sector to spend more. Unfortunately there is an obstruction in the way, namely Keynes's "wages are sticky downwards" phenomenon.

The latter problem can of course be solved by forcing pay cuts on employees, but that just leads to strikes and civil unrest. The alternative is to increase the real value of the private sector's stock of base money via the above "print and spend" ploy.

The fact is that economies do recover from recessions even where states take no specific antirecessionary measures: that happened in the 1800s in Britain and elsewhere, though of course those recoveries were slower than was desirable. Thus there must be some free market mechanism that brings about recoveries.

Say's law is one possibility, but it is fairly widely accepted that money prevents Say's law from working: that is, if the private sector thinks it has an inadequate stock of money, it just will not spend at a rate that brings full employment. That makes the Pigou effect a good contender for the mechanism which gets free markets out of recessions.

Incidentally, the important point as far as inducing the non-bank private sector to spend more goes, is the real value of that sector's stock of "net liquid assets", for want of a better phrase. (It is the non-bank private sector which will (or won't) increase spending when its stock of liquid assets rises). For example, while base money is a net asset as viewed by the private sector, every dollar issued by banks is offset by a dollar of debt owed by the non-bank private sector. (Incidentally the latter "important point" explains why advocates of Modern Monetary Theory thought up the concept "Private Sector Net Financial Assets" - sometimes shortened to PSNFA.) 
Thus the Pigou effect does not increase the value of the private non-bank sector's stock of bank created money: it's the stock of base money that is important.

Also, there is very little difference between base money and government debt, as explained by Wolf (2014). After a fall in wages and prices, the rise in the real value of government debt probably also induces the non-bank private sector to spend more.

To summarise, while there is little to prevent interest rates changing in sympathy with market forces, there is a major obstruction in the way of another of the free market's cures for a recession, that cure being to increase the real value of the private sector's stock of base money and (same thing), government debt. And if that conclusion is correct, it follows that there is correspondingly little reason to use artificial interest rate adjustments to influence demand and a correspondingly good reason to have the state create and spend new money come a recession, and/or cut taxes.

Of course "print and spend" is not an exact imitation of the Pigou effect, but it is near enough. A helicopter drop would be a closer imitation, but that involves setting up an entirely new system for distributing new money to the population and to government spending departments: i.e. a helicopter drop involves bureaucratic costs. In contrast, adjusting social security payments and other types of public spending or adjusting taxes takes place all the time under the existing system. Also, increased public spending on education, health and so on has a very quick fiscal effect on numbers employed, an effect which does no harm at all.

In contrast, the "stock of base money increasing" effect takes longer. And finally, simply handing out more to the unemployed or those on state pensions is a part of "public spending", and that part of public spending comes to the same thing as a helicopter drop at least as far as the unemployed and pensioners are concerned.

So the conclusion of this section is that interest rate cuts as a cure for recessions do not address a market failure and are thus not an appropriate cure for recessions. In contrast, having the state create and spend extra money and/or cut taxes addresses a very definite market failure. On that basis, the latter "print and spend" is the better cure for recessions.

Another point in favour of "print and spend" is we have actually been doing that, and big time, recently

That is, governments have borrowed heavily, spent the relevant money and given bonds to lenders, while at the same time quantitative easing (QE) has been implemented, which consists of the CB creating new money and buying back those bonds. That all nets out to the state creating money and spending it and/or cutting taxes.

And going back even further in history, Keynes (1933, $5^{\text {th }}$ paragraph) advocated "print and spend".

Incidentally, when referring to the demand increasing effects of expanding the real value of the stock of base money in the paragraphs below, that should be taken to include the latter fiscal effect, even where matters fiscal are not mentioned. Also the phrase "print and spend" should be taken to include the possibility that the relevant government may also do a bit of "print and cut taxes". 


\section{Politicians' and CBs' responsibilities}

Another apparent problem thrown up by a zero borrowing regime and the "print and spend" method of imparting stimulus that follows in its train is that the division of responsibilities as between CB and government would need re-thinking. In particular: who exactly decides how much to print and spend in any given year, and who decides what to spend the money on?

Clearly it is unacceptable for the CB to decide how much to spend on education, defence, social security and so on: those are political decisions.

In fact the solution to the latter problem was devised a few years ago by Dyson and Jackson (2012: Chapter 7) and Dyson et al (2010: 10-12). As the latter work put it, "We recommend that an independent body, the Money Creation Committee should take decisions over how much money should be created, while the elected government of the day should make the decision over how that money will be spent."

As Dyson explains in both of the latter works, it does not really matter where the latter body is based: it could be based at the CB. The important point is that it is as free of political influence as possible. Indeed, in the case of the UK, the above "independent body" could perfectly well be the existing Bank of England Monetary Policy Committee. Plus independent committees of that sort have become increasingly common in recent years, so we are half way to implementing the latter "Dyson" idea anyway (for example the UK's “Office for Budget Responsibility" (OBR)). The latter "Dyson" solution got support of a sort from Ben Bernanke. See Matthews (2016), paragraph starting "A possible arrangement...".

\section{CB independence}

Having said it is desirable to keep politicians away from the latter sort of committee, that point is actually debatable. The Bank of England was not granted independence till 1997: that is, it was at least nominally under the control of a politician, the UK finance minister. But inflation was not a huge problem for most of the time between the end of WWII and 1997. There was of course the 1970s inflationary episode, but that is not generally attributed in the UK to the Bank of England's lack of independence. Also Jácome and Vázquez (2005) found little relationship between CB independence and inflation in South America and the Caribbean.

However, the consensus seems to be that it is best for CBs to have a significant amount of independence, and on that assumption, Dyson's proposed split of responsibilities is a neat way of implementing "print and spend".

Finally, readers acquainted with Dyson's work may be concerned that his main objective was to argue for full reserve banking (also known as "Sovereign Money" and "Vollgeld"), and thus that absent full reserve, the argument for independent committees of the above sort loses relevance. In fact his split of responsibilities would work under the existing bank system just as well as under full reserve: indeed it is already doing so in the UK in that the OBR has been up and running for nearly a decade, but the UK has not implemented full reserve banking.

\section{CONCLUSION}

Hopefully the basic argument put in this paper has been successfully made, that argument being as follows.

1. The arguments for government borrowing are badly flawed. If those arguments are all totally invalid, it follows that governments should borrow nothing and that amounts to a permanent zero interest rate policy. 
2. Feeble as the arguments for borrowing to fund public investments are, it is just possible that at some time in the future, advocates of that borrowing manage to demonstrate the optimum amount of such borrowing, perhaps expressed as a percentage of GDP. But having done that, CBs cannot then create fresh base money and buy up those bonds with a view to influencing interest rates because that contradicts the claim that public investments should be funded via borrowing.

Moreover, the big market failure in real world free markets is not the failure of interest rates to fall: it is the fact that Keynes's "wages are sticky downwards" phenomenon stops the market increasing the real value of the non-bank private sector's stock of money, and that being the case, the logical response to a recession is to have the state create money and spend it, and/or cut taxes, rather than adjust interest rates.

3. An absence of government borrowing rules out fiscal stimulus in the form of extra public spending or tax cuts funded by government borrowing. It also rules out, or at least makes interest rate adjustments more difficult.

4. However, disposing or largely disposing of the latter two forms of stimulus is not a problem, since stimulus can be imparted by having the state create and spend more base money, and/or cut taxes. The latter ploy has much the same effect as the latter "perfect market minus the "wages are sticky downwards" flaw: that is, it raises the real value of the non-bank private sector's stock of money.

A final and incidental point is that there is a logical connection of a sort between the basic argument in this paper and full reserve banking (also known as "Sovereign money" and "Vollgeld"). The connection is thus.

Under full reserve, money created by commercial banks is banned. Ergo a significant proportion of that money is replaced with base money (if not all of it). Ergo it is difficult or impossible to alter interest rates other than by paying interest on reserves, but as pointed out above, that makes as much sense as rewarding people for keeping wads of $\$ 100$ bills under their mattresses. Certainly Dyson (2010), a work which advocates full reserve, argues against interest rate adjustments.

\section{References}

Dyson, B., Greenham, T., Ryan-Collins, J. \& Werner, R. 2010. Towards a twenty-first century banking and monetary system.

http://b.3cdn.net/nefoundation/3a4f0c195967cb202b_p2m6beqpy.pdf

Dyson, B., \& Jackson, A. 2012. Modernising money. London. Positive Money.

Forstater, M., \& Mosler, W. 2005. The natural rate of interest is zero. Journal of economic issues. 39(2), 535-542. http://dx.doi.org/10.1080/00213624.2005.11506832

Friedman, M. 1948. A monetary and fiscal framework for economic stability. American economic review. 17(3), 330. http://dx.doi.org/10.2307/1907322

Hume, D. 1742. Of public credit.

http://www.econlib.org/library/LFBooks/Hume/hmMPL32.html

Jácome, L., \& Vázquez, F. 2005. Any link between legal CB independence and inflation? evidence from Latin America and the Caribbean.

http://www.imf.org/external/pubs/ft/wp/2005/wp0575.pdf

Kellerman, K. 2006. Debt financing of public investment: On a popular misinterpretation of "the golden rule of public sector borrowing." European journal of political economy. 23(4),1088-1104.

http://dx.doi.org/10.1016/j.ejpoleco.2006.03.006

Keynes, J. 1933. An open letter to president roosevelt.

http://www.scribd.com/doc/33886843/Keynes-NYT-Dec-31-1933 
Matthews, C. 2016. Here's how Ben Bernanke's "Helicopter Money" plan might work. Fortune. http://fortune.com/2016/04/12/bernanke-helicopter-money/

Mitchell, W.F. 2014. There is no need to issue public debt. Billyblog.

http://bilbo.economicoutlook.net/blog/?p=31715

Mosler, W. 2010. Proposals for the banking system. Huffington post. http://www.huffingtonpost.com/warren-mosler/proposals-for-the-banking_b_432105.html

Murphy, R. 2018. The country wants and needs more government debt. Tax research UK.

http://www.taxresearch.org.uk/Blog/2018/06/20/the-country-wants-and-needs-more-government-debt/

Musgrave, R. 1939. The nature of budgetary balance and the case for the capital budget. American economic review. 29 (2): 260-271.

https://www.jstor.org/stable/1803624?seq=1\#page_scan_tab_contents

Musgrave, R.S. 2018a. A permanent zero interest rate would maximise GDP. Munich personal RePEc archive. https://mpra.ub.uni-muenchen.de/87111/

Musgrave, R.S. 2018b. A permanent zero interest rate would maximise GDP (second edition). Open thesis. http://www.openthesis.org/documents/permanent-zero-interest-rate-would-603707.html

Rowe, N. 2012. How time travel is possible. Worthwhile Canadian initiative. http://worthwhile.typepad.com/worthwhile_canadian initi/2012/10/how-time-travel-is-possible.html

Wolf, M. 2014. Warnings from Japan for the Eurozone. Financial times. $4^{\text {th }}$ November.

https://www.ft.com/content/35e3f7e4-6415-11e4-bac8-00144feabdc0

Wren-Lewis, S. 2018. Interest rate vs fiscal policy stabilisation. Mainly Macro. https://mainlymacro.blogspot.com/2018/08/interest-rate-vs-fiscal-policy.html 